\title{
PROFIL PENGOBATAN DAN DRP'S PADA PASIEN GANGUAN LAMBUNG (DYSPEPSIA, GASTRITIS, PEPTIC ULCER) DI RSUD SAMARINDA
}

\author{
Wahyu Widayat, Iffah Karina Ghassani, Laode Rijai \\ Fakultas Farmasi, Universitas Mulawarman, Samarinda, Indonesia. \\ *Email : widayatwahyu.r@gmail.com
}

\begin{abstract}
ABSTRAK
Lambung merupakan organ pencernaan yang terletak setelah esofagus dan sebelum duodenum yang memiliki fungsi dalam proses anabolisme makanan. Gangguan lambung dapat disebabkan oleh infeksi Helicobacteria pylori, pola makan, stres, dan efek samping dari obat NSAID dengan jumlah populasi penderita meningkat setiap tahunnya. Tujuan penelitian ini adalah untuk menganalisa gambaran mengenai karakteristik dan pola pengobatan di RSUD Samarinda pada pasien yang mengalami gangguan lambung serta profil DRP's nya. Metode penelitian yang digunakan yaitu non eksperimental. Data yang di peroleh diambil secara prospektif dan teknik pengambilan sampel yang digunakan yaitu incidental sampling. Populasi penelitian ini adalah pasien yang mengalami gangguan lambung (dyspepsia, gastritis, petic ulcer disease) yang sedang menjalani terapi di RSUD Samarinda. Hasil penelitian menunjukkan bahwa pasien yang mengalami gangguan lambungdi dominasi oleh perempuan 55,7\%, pada kelompok usia lansia awal 46-55 tahun $36,5 \%$, pendidikan terakhir adalah SD 40,4\%, pekerjaan wiraswasta $36,5 \%$, mengonsumsi obat NSAID 59,6\%, dan merokok 65,2\%. Pasien dengan pola makan sering mengonsumsi makanan pedas $82,7 \%$, mengonsumsi kopi $53,8 \%$, dan makan tidak teratur $17,3 \%$. Pola pengobatan yang diberikan saat di Rumah Sakit adalah pola pengobatan 1 yaitu 36,5\%, pola pengobatan 4 sebesar 57,7\% dan pola pengobatan 13 sebesar 5,8\%. Dugaan terhadap profil DRP's adalah interaksi obat moderate $80,6 \%$ dan interaksi obat minor $12,8 \%$. Ada indikasi tidak mendapatkan terapi sebanyak $23 \%$ dan mendapatkan terapi tanpa indikasi sebanyak $5,7 \%$. Pasien yang mengonsumsi Herbal dari kunyit dan temulawak sebanyak $65,4 \%$.
\end{abstract}

Kata kunci: Dyspepsia, Gastritis, Peptic Ulcer Disease, DRP's

\begin{abstract}
Gastric is the gastrointestinal organ which located after the esophagus before the duodenum and has a function in the process of food anabolism. Gastric disorders can be caused by Helicobacteria pylori infection, eating habit, stress, and side effects of NSAID drugs with the number of patients increasing each year. The purpose of this study is to analyze the characteristics and patterns of treatment in RSUD Samarinda to patients who have gastric disorders and DRP's profile. The research method used was non experimental. The data obtained were taken prospectively and the sampling technique used was incidental sampling. The research population were patients with gastric disorders (dyspepsia, gastritis, peptic ulcer disease) who were undergoing therapy at RSUD Samarinda. The results showed that patients with gastric disorders were dominated by women (55.7\%), elderly 46-55 years old (36.5\%), elementary school educational background (40.4\%), private employees(36.5\%), taking NSAID drugs (59.6\%) and smoke
\end{abstract}


(65.2\%). Patients often eat spicy (82.7\%), drink coffee (53.8\%), and do not eat regularly (17.3\%). Meanwhile, the patients receiving treatment pattern at the hospital were given treatment pattern 1 (36,5\%), treatment pattern 4 (57,7\%), treatment pattern 13 (58,8\%). Presumptions towards DRPs profile is moderate drug interactions $80.6 \%$ and minor drug interactions $12.8 \%$. As much of $23 \%$ of the patients showed certain indication but did not given any therapy, while as much of $5.7 \%$ of the patients were getting therapy without showing certain indication. As much of $65.4 \%$ patients take herbs (Turmeric and Curcuma)

\section{Keywords: DRP, Dyspepsia, Gastritis, Peptic Ulcer Disease}

\section{DOI: https://doi.org/10.25026/jsk.v1i10.100}

\section{PENDAHULUAN}

Gangguan lambung dapat terjadi disebabkan oleh ketidakseimbangan antara faktor agresif (HCL dan pepsin) dan faktor defensif (pertahanan mukosa lambung). Gangguan lambung yang mungkin terjadi di masyarakat terdiri dari dyspepsia, gastritis dan peptic ulcer disease. Prevalensi kejadian gangguan lambung di Indonesia mengalami peningkatan setiap tahunnya. Pengobatan untuk mengatasi gangguan lambung dapat dilakukan secara farmakologi dengan pemberian obat-obat sintetik golongan PPI, H2-Blocker, antasida dan sukralfat $^{[1]}$.

Selain itu, juga dapat diberikan obat-obat herbal atau jamu yang berasal dari tanaman keluarga zingiberaceae seperti jahe, kunyit, temulawak dan pegagan ${ }^{[2]}$. Pada saat pengobatan yang diberikan pada pasien gangguan lambung dapat terjadi beberapa masalah yang dikenal dengan Drug Related Problems (DRPs). Drug Related Problems (DRPs) adalah masalah yang diperkirakan akan terjadi berkaitan dengan terapi obat yang sedang digunakan oleh pasien. Terapi pada pasien gangguan lambung sering mendapatkan kombinasi obat. Penggunaan beberapa obat secara bersamaan memudahkan terjadinya interaksi obat. Masalah lain terkait terapi pada pasien ganggaun lambung yaitu ada indikasi tidak mendapatkan terapi, mendapatkan terapi tanpa indikasi, dosis kurang, dosis lebih, dan pemberian obat yang kurang tepat ${ }^{[3]}$.

\section{METODE}

Metode penelitian yang digunakan ialah non eksperimental dengan jenis penelitian kualitatif. Pengumpulan data dilakukan secara prospektif dari bulan september hingga desember 2017 dengan menganalisa data rekam medik pasien dan melakukan wawancara. Sampel ditentukan menggunakan metode incidental sampling sesuai dengan kriteria inklusi. Jumlah sampel pada penelitian ini sebanyak 52 pasien.

Kriteria inklusi pada penelitian ini yaitu pasien dengan diagnosa mengalami dyspepsia, gastritis, peptic ulcer disease dengan atau tanpa komplikasi menjalani rawat inap atau rawat jalan di RSUD Abdul Wahab Sjahranie Samarinda periode September-Desember 2017 dan berusia minimal 17 tahun. Data yang di peroleh dianalisis secara deskriptif diolah menjadi bentuk persentase, disajikan dalam bentuk tabel.

\section{HASIL DAN PEMBAHASAN}

Distribusi karakteristik pasien gangguan lambung berdasarkan usia, jenis kelamin, pendidikan, pekerjaan, konsumsi obat NSAID, merokok dan pola makan dapat dilihat pada Tabel 1, 2, $3,4,5,6$, dan 7 . 
Tabel 1. Distribusi Karakteristik Pasien Gangguan Lambung Berdasarkan Usia

\begin{tabular}{cccc}
\hline Kategori Usia & Rentang Usia (tahun) & Jumlah (Orang) & Persentase (\%) \\
\hline Remaja Akhir & $17-25$ & 4 & 7,7 \\
Dewasa Awal & $26-35$ & 4 & 7,7 \\
Dewasa Akhir & $36-45$ & 9 & 17,3 \\
Lansia Awal & $46-55$ & 19 & 36,5 \\
Lansia Akhir & $56-70$ & 16 & 30,6 \\
\hline & & 52 & 100 \\
\hline
\end{tabular}

Tabel 2 Distribusi Karakteristik Pasien Gangguan Lambung Berdasarkan Jenis Kelamin

\begin{tabular}{ccc}
\hline Jenis Kelamin & Jumlah (orang) & Persentase (\%) \\
\hline Laki-Laki & 23 & 44,2 \\
Perempuan & 29 & 55,7 \\
\hline Total & 52 & 100 \\
\hline
\end{tabular}

Tabel 3. Distribusi Karakteristik Pasien Gangguan Lambung Berdasarkan Pendidikan

\begin{tabular}{ccc} 
Riwayat Pendidikan & Jumlah (orang) & Persentase $(\%)$ \\
SD & 21 & 40,4 \\
SMP & 11 & 21,2 \\
SMA & 15 & 28,8 \\
Sarjana & 5 & 9,6 \\
\hline Total & 52 & 100
\end{tabular}

Tabel 4 Distribusi Karakteristik Pasien Gangguan Lambung Berdasarkan Pekerjaan

\begin{tabular}{ccc}
\hline Pekerjaan & Jumlah (orang) & Persentase $(\%)$ \\
\hline Tidak Bekerja & 2 & 3,8 \\
Wiraswasta & 19 & $21,236,5$ \\
Wirausaha & 5 & 9,6 \\
Petani & 8 & 15,4 \\
PNS & 7 & 13,5 \\
IRT & 10 & 19,2 \\
Pelajar & 1 & 2 \\
\hline Total & 52 & 100 \\
\hline
\end{tabular}

Tabel 5 Distribusi Karakteristik Pasien Gangguan Lambung Berdasarkan Konsumsi Obat NSAID

\begin{tabular}{ccc}
\hline Konsumsi Obat NSAID & Jumlah (orang) & Persentase (\%) \\
\hline Mengonsumsi & 31 & 59,6 \\
Tidak mengonsumsi & 21 & 40,4 \\
\hline Total & 52 & 100 \\
\hline
\end{tabular}

Tabel 6. Distribusi Karakteristik Pasien Gangguan Lambung Berdasarkan Merokok

\begin{tabular}{ccc}
\hline Merokok & Jumlah (orang) & Persentase (\%) \\
\hline Merokok & 15 & 65,2 \\
Tidak merokok & 8 & 34,8 \\
\hline Total & 23 & 100 \\
\hline
\end{tabular}


Tabel 7. Distribusi Karakteristik Pasien Gangguan Lambung Berdasarkan Pola Makan

\begin{tabular}{ccc}
\hline Pola makan & Jumlah (orang) & Persentase $(\%)$ \\
\hline Konsumsi makanan pedas & 43 & 82,7 \\
Makan tidak teratur & 34 & 17,3 \\
Konsumsi kopi & 28 & 53,8 \\
\hline
\end{tabular}

Berdasarkan tabel 1 rentang usia 46-55 tahun memiliki angka kejadian gangguan lambung paling tinggi yaitu dengan presentase sebesar 36,5\%. Menurut Ariefiany (2014) hal itu dapat terjadi dikarenakan tingkat usia seseorang mempengaruhi penurunan fungsi dari suatu organ. Pada usia tua memiliki resiko lebih tinggi mengalami gangguan lambung dibanding dengan usia muda. Hal ini menunjukkan bahwa seiring dengan bertambahnya usia seseorang, mukosa lambung cenderung menjadi tipis dan produksi mukus (cairan pelindung lambung) berkurang sehingga lebih mudah mengalami iritasi pada mukosa lambung ${ }^{[4]}$

Berdasarkan tabel 2 perempuan memiliki angka kejadian gangguan lambung paling tinggi yaitu sebesar $55,7 \%$. Hal ini dikarenakan wanita lebih emosional dan lebih mudah mengalami stres dibanding pria secara psikologis. Wanita cenderung memikirkan suatu hal secara mendalam dapat menyebabkan wanita mudah mengalami stres. Secara biologis, wanita lebih mudah mengalami stres dikarenakan terjadi perubahan sistem hormonal di dalam tubuh ${ }^{[5]}$.

Saat seseorang mengalami stres, akan terjadi rangsangan yang akan dibawa menuju hipotalamus di otak sehingga melepaskan corticotrophin releasing factor (CRF). $\mathrm{CRF}$ menstimulasi pelepasan adenocorticotrophin hormon (ACTH) sehingga merangsang kelenjar adrenalin untuk menghasilkan beberapa hormon salah satunya adalah hormon kortisol. Produksi hormon kortisol akan meningkat saat stres. Pada lambung, pengaruh produksi hormon kortisol yang tinggi dapat meningkatkan produksi asam lambung ${ }^{[6]}$.

Berdasarkan tabel 3, tingkat pendidikan Sekolah Dasar (SD) memiliki angka kejadian gangguan lambung paling tinggi yaitu sebesar 40,4\%. Hal ini dikarenakan tingkat pendidikan seseorang mempengaruhi pengetahuan seseorang dalam suatu penyakit. Pendidikan berfungsi sebagai alat bantu untuk memberikan dan mengajarkan berbagai pengetahuan khususnya tentang penyakit tertentu. Tingkat pendidikan mempengaruhi seseorang dalam menerima informasi baik itu informasi tentang kesehatan, penyakit, pengobatan dan lain sebagainya. Seseorang dengan tingkat pendidikan lebih baik akan lebih mudah menerima informasi dibanding dengan orang dengan tingkat pendidikan yang kurang. Dengan demikian, semakin tinggi tingkat pendidikan seseorang, maka tingkat pengetahuan dalam hal pemahaman mengenai suatu penyakit akan lebih mudah ${ }^{[7]}$.

Berdasarkan tabel 4, pekerjaan sebagai wiraswasta memiliki angka kejadian gangguan lambung paling tinggi yaitu sebesar 36,5\%. Pekerjaan merupakan salah satu faktor yang dapat memicu kemungkinan terjadinya resiko gangguan lambung. Dikarenakan tuntutan pekerjaan dan kesibukan yang membuat seseorang memiliki pola dan frekuensi makan yang tidak teratur sehingga dapat menyebabkan terjadinya gangguan lambung. Selain itu tuntutan dan tekanan yang dialami dalam pekerjaan dapat membuat seseorang mengalami stres yang dapat memicu terjadinya gangguan lambung ${ }^{[8]}$.

Berdasarkan tabel 5, pasien yang mengonsumsi obat NSAID memiliki 
angka kejadian gangguan lambung paling tinggi yaitu sebesar 59,6\%. Hal ini dikarenakan obat golongan NSAID dapat menghambat enzim siklooksigenase 1 yang mengubah asam arakhidonat menjadi prostaglandin yang bersifat protektor terhadap mukosa lambung ${ }^{[9]}$.

Obat NSAID nonselektif terdiri dari aspirin, indometasin, piroxicam, ibuprofen, naproxen, dan asam mefenamat. NSAID COX-2 prefential yaitu meloxicam dan diklofenak. NSAID selektif COX-2 yaitu celecoxib. Sehingga obat NSAID yang aman untuk pasien gangguan lambung adalah celecoxib karena selektif COX-2 yaitu hanya menghambat enzim siklooksigenase 2 sehingga tidak menghasilkan prostaglandin yang bersifat sebagai mediator nyeri dan inflamasi ${ }^{[10]}$.

Berdasarkan tabel 6, pasien yang merokok memiliki angka kejadian gangguan lambung paling tinggi yaitu sebesar 65,2\%. Merokok dapat mengakibatkan kerusakan pada lambung dikarenakan sekresi asam lambung yang berlebih. Sekresi asam lambung yang berlebih diakibatkan oleh zat yang terkandung dalam asap rokok seperti nikotin dan asam nikotinat yang dapat menurunkan rangsangan pada pusat makan di sistem saraf pusat sehingga membuat seseorang menjadi tidak lapar. Jika tidak ada makanan yang dicerna oleh lambung, maka asam lambung akan mencerna lapisan lambung dan mengakibatkan iritasi pada lambung ${ }^{[11]}$.

Berdasarkan tabel 7, diperoleh pasien dengan pola makan sering mengonsumsi makanan pedas sebesar $82,7 \%$, makan tidak teratur sebesar $17,3 \%$ dan sering mengonsumsi kopi sebesar 53,8\%. Menurut Sediaoetama (2010), mengonsumsi makanan pedas secara berlebihan akan merangsang sistem pencernaan, terutama lambung dan usus untuk berkontraksi dan menimbulkan rasa panas dan nyeri pada lambung disertai rasa mual dan muntah. Jika mengonsumsi makanan pedas lebih dari satu kali dalam seminggu selama 6 bulan akan mengakibatkan iritasi pada lambung dan menyebabkan gangguan lambung ${ }^{[12]}$. Menurut penelitian yang dilakukan teng (2013), pemberian cabai terus menerus pada lambung akan menyebabkan iritasi pada lambung. Cabai mengandung capcaisin yang bersifat iritan bagi lambung. Capcaisin memiliki reseptor TRPV-1 yang menyebabkan rasa panas pada lambung dan meningkatkan produksi asam lambung. Jika terus mengonsumsi cabai atau makanan pedas akan menyebabkan iritasi dan kerusakan pada lambung ${ }^{[13]}$.

Mengonsumsi kopi secara terus menerus dapat menyebabkan gangguan lambung dikarenakan kafein yang terkandung pada kopi akan meningkatkan sekresi gastrin yang merangsang produksi asam lambung. Kafein mengandung senyawa asam diantaranya caffeic acid dan chlorogenic acid yang memicu terjadinya gangguan lambung ${ }^{[14]}$.

\section{Distribusi Pasien Gangguan Lambung Berdasarkan Pola Pengobatan}

Penelitian ini menunjukkan pola pengobatan yang paling banyak digunakan oleh pasien gangguan lambung adalah pola pengobatan 2 yaitu kombinasi obat golongan PPI dengan sukralfat sebesar $57,7 \%$. Menurut Song (2015) obat golongan Proton Pump Inhibitor efektif menurunkan kejadian penyakit Peptic Ulcer Disease karena dapat menghambat asam lambung dengan menghambat langsung kerja enzim $\mathrm{K}^{+} \mathrm{H}^{+}$ ATPase yang akan memecah $\mathrm{K}^{+} \mathrm{H}^{+}$ATP menghasilkan energi yang digunakan untuk mengeluarkan asam lambung $(\mathrm{HCl})$ dari kanakuli sel parietal ke dalam lumen lambung. Proton Pump Inhibitor merupakan penghambat sekresi asam lambung lebih kuat dibanding obat golongan $\mathrm{H}_{2}$-Blocker ${ }^{[15]}$.

Sukralfat merupakan kompleks aluminium hidroksida dan sukrosa sulfat yang efeknya sebagai antasida minimal. Sukralfat bekerja dengan cara membentuk 
lapisan pada dasar tukak sehingga melindungi tukak dari pengaruh agresif asam lambung dan pepsin. Sukralfat digunakan untuk mengobati penyakit tukak lambung ${ }^{[16]}$.

Terapi yang digunakan untuk mengeradikasi bakteri Helicobacter pylori haruslah efektif, dapat ditoleransi dengan baik, regimen terapi dapat meningkatkan kepatuhan pasien dalam menggunakan obat dan cost-effective ${ }^{[17]}$.

Penggunaan antibakteri secara tunggal tidak akan mensukseskan tujuan eradikasi tetapi bahkan dapat mempercepat kecepatan resistensi dari antibakteri itu sendiri. Regimen obat untuk eradikasi bakteri $H$. pylori yang direkomendasikan mengkombinasikan dua antibakteri dengan satu agen antisekretori (tripel regimen) atau bismuth subsalisilat dengan dua antibakteri (berbeda jenis dengan tripel regimen) dan satu agen antisekretori (quadripel regimen) sehingga dapat meningkatkan kecepatan eradikasi dan menurunkan risiko resistensi antibakteri. Tata laksana awal yang paling sering digunakan yaitu triple therapy yang terdiri dari PPI, amoksisilin dan klaritromisin yang diberikan 2 kali sehari selama 7-14 hari ${ }^{[17]}$.

Tabel 8. Distribusi Pola Pengobatan Pasien Gangguan Lambung

\begin{tabular}{ccccc}
\hline Pola & Gol Obat A & Gol Obat B & Jumlah & $\%$ \\
\hline Pola 1 & PPI atau H2 Blocker & & 19 & 36,5 \\
Pola 2 & PPI & Sukralfat & 30 & 57,7 \\
Pola 3 & Antibiotik & Pola 2 & 3 & 5,8 \\
\hline
\end{tabular}

Tabel 9. Distribusi Pasien Gangguan Lambung Berdasarkan Interaksi Obat

\begin{tabular}{|c|c|c|c|c|}
\hline Interaksi Obat & Obat A & Obat B & Jumlah Kejadian & $\%$ \\
\hline Moderete & Sukralfat & Lansoprazol & 24 & $85,6 \%$ \\
\hline Minor & Amoksisilin & Klaritromisin & 1 & $3,6 \%$ \\
\hline Minor & Klaritromisin & Omeprazol & 1 & $3,6 \%$ \\
\hline Minor & Ranitidin & Parasetamol & 1 & $3,6 \%$ \\
\hline \multirow[t]{2}{*}{ Minor } & Vitamin B12 & Lansoprazol & 1 & $3,6 \%$ \\
\hline & & & 28 & $100 \%$ \\
\hline
\end{tabular}

Keterangan: data diperoleh dari drugs.com

Tabel 10. Distribusi Pasien Gangguan Lambung

\begin{tabular}{ccc}
\hline Profil DRP & Jumlah (orang) & Persentase (\%) \\
\hline Dosis yang kurang Tepat & 15 & 28,8 \\
Dosis tepat & 37 & 71,2 \\
\hline & 52 & 100 \\
\hline
\end{tabular}

Tabel 11 Distribusi Pengobatan Pasien Berdasarkan Mengonsumsi Herbal dari kunyit dan temulawak

\begin{tabular}{ccc}
\hline Obat Herbal & Jumlah (Pasien) & Persentase (\%) \\
\hline Mengkonsumsi & 34 & $65,4 \%$ \\
Tidak Mengkonsumsi & 18 & $34,6 \%$ \\
\hline
\end{tabular}




\section{Distribusi Pasien Gangguan Lambung Berdasarkan DRP's}

Dari hasil penelitian menunjukkan interaksi obat berdasarkan tingkat keparahan moderate sebesar $80,6 \%$ dengan jumlah kejadian sebanyak 25 kasus. Interaksi minor sebesar $12,8 \%$ dengan jumlah kejadian sebanyak 4 kasus.

Menurut drug interactions checker interaksi antara obat sukralfat dengan lansoprazol termasuk interaksi obat dengan tingkat keparahan moderate. Oleh karena itu lansoprazol harus diberikan 1 jam sebelum atau sesudah pemberian sukralfat. Sebuah interaksi termasuk ke dalam keparahan moderate jika satu dari bahaya potensial mungkin terjadi pada pasien, dan beberapa tipe intervensi atau monitor sering diperlukan. Efek interaksi moderate mungkin menyebabkan perubahan status klinis pasien, perawatan tambahan, perawatan di rumah sakit dan atau perpanjangan lama tinggal di rumah sakit $^{[18]}$.

Pada penelitian ini ditemukan interaksi obat potensial dengan tingkat keparahan moderate antara lansoprazol dengan sukralfat. Setelah dianalisis, obat diberikan pada rute pemberian yang berbeda. Pemberian obat pada rute yang berbeda ini tidak memungkinkan untuk terjadinya interaksi. Sehingga dapat dikatakan bahwa tindakan yang diberikan pada pasien sesuai untuk mencegah terjadinya interksi obat potensial tersebut. Pada pasien lainnya lansoprazol dengan sukralfat diberikan pada rute oral tetapi dengan waktu pemberian yang berbeda. Sukralfat diberikan 1 jam sebelum makan dan lansoprazol diberikan 1 jam setelah makan. Dengan pemberian waktu yang berbeda maka tidak memungkinkan untuk terjadi interaksi ${ }^{[18]}$.

Interaksi obat minor umumnya tidak menimbulkan bahaya atau memerlukan perubahan terapi. Interaksi dengan tingkat keparahan minor adalah interaksi yang mungkin terjadi tetapi dipertimbangkan signifikan potensial berbahaya terhadap pasien jika terjadi kelalaian. Interaksi obat minor biasanya tidak menimbulkan bahaya atau memerlukan perubahan terapi ${ }^{[18]}$.

Menurut drug interactions checker yang termasuk interaksi obat dengan tingkat keparahan minor pada penelitian ini yaitu interaksi antara antibiotik klaritomisin dengan amoksisilin, parasetamol dengan ranitidin, omeprazol dengan klaritromisin, dan interaksi antara vitamin B12 dengan lansoprazol. Klaritromisin dapat menurunkan efek dari amoksisilin jika diberikan secara bersamaan. Pemberian klaritromisin 500 mg 2 kali sehari selama 7 hari menyebabkan kenaikan 2 kali lipat dalam AUC omeprazol. Lansoprazol dapat menurunkan kadar vitamin B12 dengan cara menghambat penyerapan pada saluran GI ${ }^{[19]}$

Ranitidin dapat menghambat enzim glucoronyltransferase sehingga parasetamol tidak bisa di metabolisme di hati. Disarankan agar pemberian obatobat yang berinteraksi sebaiknya diberikan pada waktu yang berbeda untuk meningkatkan atau mencegah penurunan efektivitas terapi. Namun potensi interaksi obat minor yang terjadi tidak bermakna secara klinis ${ }^{[19]}$.

\section{Berdasarkan Ketepatan Dosis}

Pada DRP's ketepatan dosis ditemukan pemberian obat dengan dosis yang kurang tepat sebanyak $28,8 \%$. Pada pasien 015, 033, 043, 046 diberikan obat lansoprazol dengan dosis 2 kali sehari 30 mg. Menurut Aberg (2009), dosis lansoprazol untuk pasien peptic ulcer disease dan gastric ulcer diberikan 1 kali sehari sebanyak $30 \mathrm{mg}$ selama 8 minggu. Secara farmakokinetik lansoprazol memiliki indeks terapi luas. Semakin lebar indeks terapi berarti jarak antara dosis terapi dengan dosis toksik semakin lebar. Sehingga peningkatan dosis yang sedikit tidak menyebabkan efek toksik dari penggunaan obat tersebut ${ }^{[20]}$. 
Pada pasien 007, 011, 018, 021, 034, 048 diberikan obat omeprazol dengan dosis 2 kali sehari $20 \mathrm{mg}$. Menurut Aberg (2009), dosis omeprazol untuk pasien peptic ulcer disease dan gastric ulcer diberikan 1 kali sehari sebanyak $40 \mathrm{mg}$ selama 4-8 minggu. Secara farmakokinetik, omeprazol memiliki waktu paruh eliminasi 30-60 menit di dalam plasma darah. Sehingga dengan penambahan regimen dosis akan menjaga obat tetap stabil di dalam plasma darah. Selain itu omeprazol memiliki indeks terapi luas. Semakin lebar indeks terapi berarti jarak antara dosis terapi dengan dosis toksik semakin lebar. Sehingga penambahan regimen dosis tidak menyebabkan efek toksik dari penggunaan obat tersebut ${ }^{[20]}$.

Pada pasien 019, 023, 040, 042, 045 diberikan obat sukralfat dengan dosis 2 kali sehari dan 1 kali sehari $500 \mathrm{mg}$. Menurut Aberg (2009), dosis sukralfat untuk pasien gangguan lambung 4 kali sehari 1 gram. Pemberian dosis kurang mengakibatkan obat bekerja tidak maksimal dalam memberikan efek ${ }^{[20]}$.

\section{Distribusi Pasien Berdasarkan Mengonsumsi Obat Herbal}

Berdasarkan tabel 11, pasien yang mengonsumsi herbal dari kunyit dan temulawak memiliki angka kejadian gangguan lambung paling tinggi yaitu dengan persentase sebesar $65,4 \%$. Kurkumin yang dikandung temulawak selain mengandung senyawa fenolik, juga memiliki aktifitas menekan pembentukan NF-kB yang merupakan faktor transkripsi sejumlah gen penting dalam proses imunitas dan inflamasi, salah satunya untuk membentuk TNF- $\alpha$. Dengan menekan kerja NF-kB maka radikal bebas dari hasil sampingan inflamasi berkurang ${ }^{[21]}$.

Menurut Dong Chan (2005), kunyit memiliki efek yang sama dengan obat golongan H2-Blocker dalam mengobati luka pada lambung yaitu dengan menghambat peningkatan cAMP akibat rangsangan dimaprit, yang merupakan agonis reseptor histamin. Sehingga histamin yang dihasilkan di sel parietal lambung tidak terbentuk dan menyebabkan berkurangnya sekresi asam lambung dan pepsin ${ }^{[22]}$.

\section{KESIMPULAN}

1. Karakteristik pasien gangguan lambung berdasarkan usia paling banyak ditunjukkan pada rentang usia 46-55 tahun sebanyak 36,5\%. Berdasarkan jenis kelamin didominasi oleh wanita sebanyak 55,7\%, pendidikan terakhir yaitu SD sebanyak 40,4\%, pekerjaan yaitu wiswasta $36,5 \%$, merokok $65,2 \%$, konsumsi NSAID sebanyak 59,6\%, pola makan pasien dengan kategori konsumsi makanan pedas sebanyak $82,7 \%$, tidak makan teratur sebanyak $17,3 \%$ dan konsumsi kopi sebanyak $53,8 \%$.

2. Pola pengobatan pasien yang paling banyak digunakan yaitu pola pengobatan 2 sebesar $57,7 \%$

3. Profil DRP's yang ditemukan pada penelitian ini yaitu interaksi obat dengan tingkat keparahan moderate sebanyak $80,6 \%$ dan tingkat keparahan minor sebanyak $12,8 \%$. DRP's kategori ada indikasi tidak mendapatkan terapi sebanyak 23\% dan mendapatkan terapi tanpa indikasi sebanyak 5,7\%. Dan DRP's berdasarkan dosis kurang tepat sebesar $28,8 \%$.

4. Pengobatan herbal terdiri dari pasien yang mengonsumsi sebesar $65,4 \%$ dan tidak mengonsumsi sebesar $34,6 \%$.

\section{DAFTAR PUSTAKA}

[1]. Dipiro, J,T. et al. 2008. Pharmacotherapy: A Phatophysiological approach Seventh Edition. Mc Graq Hill Companie. 
[2]. Misnadiarly. 2009. Mengenal Penyakit Organ Cerna Gastritis (Dyspepsia atau Maag). Pustaka Populer OBDA. Jakarta.

[3]. Setiawati, A. 2007. Farmakologi dan Terapi Edisi 5. Fakultas UI. Jakarta

[4]. Ariefiany, Deassy dkk. 2014. Analisis Gambaran Hispatologi Gastritis Kronik dengan dan Tanpa Bakteri H.pylori Menurut Sistem Sidney. Majalah Patologi Volume 23 Nomor 2.

[5]. Sunaryo, 2006. Psikologi Untuk Keperawatan. EGC. Jakarta.

[6]. Lisdiana, 2012. Regulasi Kortisol Pada Kondisi Stres dan Addiction. Jurnal Biosantifika volume 4 nomor 1.

[7]. Cholifatun. 2015. Hubungan Tingkat Pendidikan, Tingkat Pengetahuan Dan Pola Asuh Ibu Dengan Wasting Dan Stunting Pada Balita Keluarga Miskin. Media Gizi Indonesia Volume 10 No 1.

[8]. Prasetyo, Danang. 2015. Hubungan Antara Stres Dengan Kejadian Gastritis di Klinik Dhanang Husada Sukoharjo. Program Studi Keperawatan Stikes Kusuma Husada Surakarta. Surakarta.

[9]. Nikose, Sunil. 2015. Gastrointestinal Adverse Effects due to Use of Non-Steroidal AntiInflammatory Drugs (NSAIDs) in Non-Traumatic Painful Musculoskeletal Disorders. Journal of Gastrointestinal \& Digestive System Volume 5 Issue 6.

[10]. Syarif, Amir dkk. 2013. Farmakologi dan Terapi Edisi 5 (cetak ulang dengan tambahan). FKUI. Jakarta.

[11]. Ardian, Ratu. 2013. Penyakit Hati lambung Usus Ambeien. Nuha Medika. Yogyakarta.
[12]. Sediaoetama, Djaeni. 2010. Ilmu Gizi. Dian Rakyat. Jakarta.

[13]. Teng, philip dkk. 2013. Gambaran Histopatologi Lambung Tikus Wistar yang Diberi Cabe Rawit. Jurnal e-Biomedik Volume 1 Nomor 3.

[14]. Anwar, F. 2009. Makan Tepat Badan Sehat. Mizan Media Utama. Jakarta.

[15]. Song, Young Rim. 2015. ProtonPump Inhibitors For Prevention Of Upper Gastrointestinal Bleeding In Patients Undergoing Dialysis. World Journal Gastroenterology Volume 21 Issue 16.

[16]. Sudoyo, dkk. 2006. Buku Ajar Ilmu Penyakit Dalam FKUI Jilid 1-3. Balai Penerbit FKUI. Jakarta

[17]. Kho, dragon. 2010. Diagnosis dan Tata Laksana Terkini Infeksi Helicobacter pylori. Majalah Kedokteran Indonesia Volume 60 Nomor 8.

[18]. Bailie, G R et al. 2004. Medfacts Pocket Guide of Drug Interaction Second Edition. Bone Care International Nephrology Pharmacy Associated. Middleton.

[19]. Claire L Preston. 2011. Stockley's Drug Interactions 11 Edition. Pharmaceutical Press. United States.

[20]. Aberg, Judith A. 2009. Drug Information Handbook. Lexi Companie. America

[21]. Bintari, GS. 2013. Temulawak (Curcuma xanthorrhiza Roxb) as Gastroprotector of Mucosal Cell Damage. Medical Faculty of Lampung University. Lampung.

[22]. Dong Chan. 2005. Curcuma longa extract protects against gastric ulcers by blocking $\mathrm{H}_{2}$ histamine receptors. Biological and Pharmaceutical Bulletin Volume 28 Number 12. 